\title{
Fanconi Anemia in the Czech Republic: role of HSCT and long-term follow-up
}

\author{
Petr Sedlacek, Petra Keslova, Petr Smisek, Martina Sukova, Marcela Malikova, Spiros Tavandzis, Jaroslav Cermak, \\ Jan Stary \\ Department of Pediatric Hematology and Oncology, $2^{\text {nd }}$ Medical School at Charles University, University Hospital Motol, \\ Prague, Czech Republic
}

Prof. Dr. Petr Sedlacek, Department of Pediatric Hematology and Oncology, $2^{\text {nd }}$ Medical School at Charles University, University Hospital Motol, V Uvalu 84, 15006 Prague,

Czech Republic
Phone: +420224436552

Fax: +420 224436519

E-mail: petr.sedlacek@lfmotol.cuni.cz

Citation: Sedlacek P, Keslova P, Smisek P et al. Fanconi Anemia in the Czech Republic: role of HSCT and long-term follow-up. Cell Ther Transplant 2020; 9(4): 48-52.

\section{Summary}

Fanconi anemia (FA) is a rare and heterogeneous syndrome associated with bone marrow failure and increased risk of cancer. While FA is often characterized by the presence of congenital malformations, in some patients cytopenia may be the only sign. In our cohort diagnosis was based on evidence of increased chromosome fragility with subsequent confirmation by gene mutation detection.

\section{Methods}

Our cohort includes 35 probands diagnosed with FA aged 0-24.3 (median 6) years between January 1986 and August 2020. Congenital anomalies at diagnosis were seen in 5 and cytopenia in 22 patients, 8 patients had family history of FA. Genetic test confirmed FANCA gene mutations in 24, FANCG in 3, FANCD1 in 4, and FANCB in 2 siblings.

\section{Results}

During follow-up 7 patients developed malignancy (among them all 4 patients with FANCD1 mutation). Seventeen patients developed marrow failure, for which 15 patients underwent allogeneic hematopoietic stem cell transplantation (HSCT) at the median age of 9.3 (4.6-24.3) years. All transplanted patients achieved stable hematopoietic engraftment. However, in 2 patients due to inadequate immune reconstitution developed fatal CMV pneumonia and invasive aspergillosis 12 and
14 months post HSCT, accordingly. In one patient we have diagnosed adenocarcinoma of the gut 10 years and squamous cell carcinoma of tongue 13 years after HSCT. Thirteen patients are alive with a median follow-up of 10.6 (0.3 - 15.1 years) years after HSCT. With a median follow-up till the last visit of $12.6(0.2-34.4)$ years $28 / 35$ (80\%) patients are alive, 4 died of malignancy, 2 died due to HSCT-related complications, and one due to severe congenital somatic defects.

\section{Conclusions}

HSCT is effective in FA patients with bone marrow failure and prevents further development of hematological malignancies. A lifelong and careful multidisciplinary follow-up of patients with FA is essential for early detection of bone marrow failure or any malignant disease.

\section{Keywords}

Fanconi anemia, somatic anomalies, gene mutations, bone marrow failure, solid tumors, hematopoietic stem cell transplantation, long-term outpatient observation. 


\section{Introduction}

Fanconi anemia (FA) is a rare inherited condition characterized by heterogeneity of clinical signs and underling genetic mutations, which significantly increase the risk of bone marrow failure or malignancy (leukemia, solid tumors) development. Fanconi anemia is characterized by the presence of congenital anomalies occurring in approximately $75-80 \%$ of affected individuals, which include one or more of the following features: small stature, abnormal skin pigmentation, upper or lower limb skeletal malformation, microcephaly, visual and urogenital anomalies $[1,2]$. The cumulative risk of developing bone marrow failure is $50 \%$. Progressive bone marrow failure typically occurs in the first decade of life often starting with thrombocytopenia or leukopenia. Leukemia and solid tumors may occur as early as in 16 years. The diagnosis of FA is based on increased chromosome fragility detection in a test with or without an agent for DNA cross-link sensitivity testing, diepoxybutane (DEB) or mitomycin C (MMC). If hematopoietic sell still possess an intact DNA repair mechanism due to mosaicism these tests may be negative in blood cells cultures. Although these situations are rare, they may complicate diagnosis and warrant for test performed in non-hematopoietic cells culture, usually fibroblasts [3]. The final diagnosis nowadays is often confirmed by detection of a mutation in one of Fanconi complex genes [4].

\section{Gene mutations in Fanconi anemia}

- Bialellic pathogenic variant of one of 19 genes causing autosomal recessive form of FA.

- Heterozygous pathogenic variant in gene RAD51 (de novo; FANCO) causing autosomal dominant form of FA.

- Hemizygous pathogenic variant in gene FANCB causing X-linked form of FA.

There is a distinct flowchart for stepwise post-diagnostic monitoring and decision making in therapy of the Fanconi anemia patients, as described, e.g., by Dufour [5].

\section{FA epidemiology in Czech Republic}

The Czech population in 2020 is 10.7 millions ( $11^{\text {th }}$ among EU countries) including 2.0 million children of 0 to 17.99 years with a birth rate of 115,000 per year. A total of 35 probands with Fanconi anemia were born in 1985-2019 in the Czech Republic with diagnosis confirmed in 1986-2020, it correlates with probable incidence of ca.1 patient/year. Diagnosis of FA was confirmed at the median age of 6 (0-24.3) years, $34 / 35$ of patients were children at the moment of diagnosis. In all cases the diagnostic procedure included spontaneous and induced chromosomal breakage evaluation, then the diagnosis was prospectively or retrospectively confirmed by specific mutation detection in 33/35 patients.

The initial symptoms registered in FA patients included congenital effects in 5, thrombocytopenia in 9, bicytopenia or pancytopenia in 13 cases, accordingly. Also, 8 patients had characteristic family history (BMF, malignancies).

The main physical abnormalities and laboratory signs incidence in our FA group $(n=35)$ at the time of diagnoses are summarized in Table 1. Table 2 and Fig. 1 contain the list and relative frequency of mutations revealed in available patients (33 of 35 cases).

Table 1. Clinical signs in 35 Fanconi anemia cases observed in Czech population

\begin{tabular}{|l|l|l|}
\hline & $\begin{array}{l}\text { No of } \\
\text { patients }\end{array}$ & $\begin{array}{l}\text { \% of } \\
\text { patients }\end{array}$ \\
\hline small stature & 31 & 89 \\
\hline abnormal skin pigmentation & 23 & 66 \\
\hline thrombocytopenia & 24 & 69 \\
\hline microcephaly & 24 & 69 \\
\hline limb skeletal malformations & 21 & 60 \\
\hline anemia & 17 & 49 \\
\hline leukopenia & 13 & 37 \\
\hline $\begin{array}{l}\text { heart and vascular congenital } \\
\text { defects }\end{array}$ & 11 & 31 \\
\hline urogenital congenital defects & 10 & 29 \\
\hline facial stigmatization & 12 & 34 \\
\hline microphtalmy, coloboma & 8 & 23 \\
\hline $\begin{array}{l}\text { psychomotor retardation, } \\
\text { autism, ... }\end{array}$ & 6 & 17 \\
\hline $\begin{array}{l}\text { gastrointestinal congenital } \\
\text { defects }\end{array}$ & 6 & 17 \\
\hline $\begin{array}{l}\text { hearing defects, ear stenosis/ } \\
\text { aplasia }\end{array}$ & 5 & 14 \\
\hline \begin{tabular}{l} 
no somatic defects \\
\hline
\end{tabular} & 0 & 0 \\
\hline
\end{tabular}

Table 2. Genetic mutations found in FA patients observed by our team

\begin{tabular}{|l|l|l|}
\hline Incidence & published & the Czech Republic \\
\hline FANCA & $60-70 \%$ & $24(=73 \%)$ \\
\hline FANCD1 & $3 \%$ & 4 \\
\hline FANCG & $9-10 \%$ & 3 \\
\hline FANCB & $2 \%$ & 2 \\
\hline FANCC & $14 \%$ & 0 \\
\hline not avail. & & 2 \\
\hline
\end{tabular}

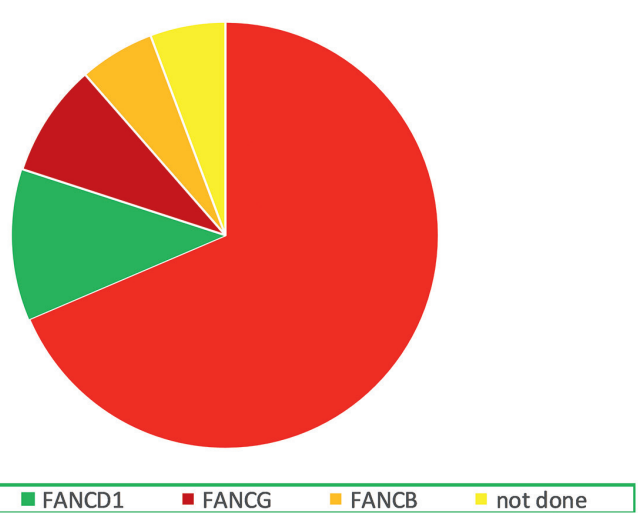

Figure 1. Relative frequency of different gene mutations in 35 FA cases from the Czech Republic 


\section{Bone marrow failure (BMF) and malignancies, outcome}

During the follow-up 17/31 (55\%) children developed BMF at the median age of $8(4.0-17.1)$ years. Five patients ( 3 boys and 2 girls) had prior history of anabolics treatment with some effect in two girls [6]. Among these, 15 patients consequently underwent allogeneic HSCT (2004-2020) at the median age of 9.3 (4.6-24.3) years.

Also, 7/35 (20\%) patients developed the following malignancies during follow-up with a median age of $9.8(1.0-32.3)$ at cancer diagnosis:

- Spinocellular carcinoma of GI (32 years); the patient died due to cancer progression,

- Gastrointestinal adenocarcinoma (at 15 years), later a squamous cell carcinoma of tongue (at 18 years); this patient had a history of HSCT at 5 years, then multiple surgical interventions were performed in order to eradicate cancers, is currently alive,

- Acute myeloid leukemia (at 6 years); this child died due to rapid leukemia progression.

Children with FANCD1 mutation (homozygous BRCA2 mutations) do not have a risk of bone marrow failure, but still the malignancies incidence is very high [7]. Among our cohort all 4 children with this mutation developed cancer early in their life. The following malignancies were registered:

- Acute lymphoblastic leukemia (at 1 year); the child responded to chemotherapy, but then a secondary acute myeloid lekemia developed and death of disease progression followed,

- Meduloblastoma (at 4.6 years); the patients died of relapse, - Nephroblastoma (at 3.7 years); the child is alive and in complete remission (these three patients are siblings),

- Medulloblastoma (1.4 years); the patient has recently finished treatment and is currently alive.

At last visit with a median follow-up of $12.6(0.2-34.4)$ years $28 / 35(80 \%)$ patients are alive, 4 died of malignancy, 2 died after HSCT and one due to severe congenital defects.

\section{Results of HSCT}

A total of 15 patients with bone marrow failure due to FA underwent allogeneic hematopoietic stem cell transplantation (HSCT) at a median age of 9.3 (4.6-24.3) years from a matched sibling donor (MSD, $\mathrm{n}=3$ ) or matched unrelated donor (MUD, $n=12$ ). The bone marrow was used in as graft source in 6, peripheral blood stem cells (PBSC) in 7 , and umbilical cord blood in 2 cases, accordingly. In al cases the pre-transplant conditioning regimen was irradiation-free. The following regimens were used: FluCy ATG in 10 cases, FluCy MbC in 1 patient, and FluCy/Bu MbC(3)/ ATG(1) in 4 patients. The regimen toxicity was acceptable and no early mortality (till D+100) was observed. All transplanted patients achieved stable hematopoietic engraftment after HSCT. Late mortality (after D+100) was registered in $2 / 15$ patients $(13 \%)$, both suffered from chronic graft- versus-host disease (GvHD), with extensive form in one case. These patients developed fatal infections due to inadequate immune reconstitution, dying of CMV pneumonia and invasive aspergillosis 12 and 14 months after HSCT, accordingly. Also, three patients require long-term immunosuppressive therapy due to chronic GvHD (limited in two cases, and extensive in one case). The patient who consequently developed two different malignancies did not suffer from chronic GvHD.

The overall survival (OS) and event-free survival (EFS) in total FA group are shown in Fig. 2.

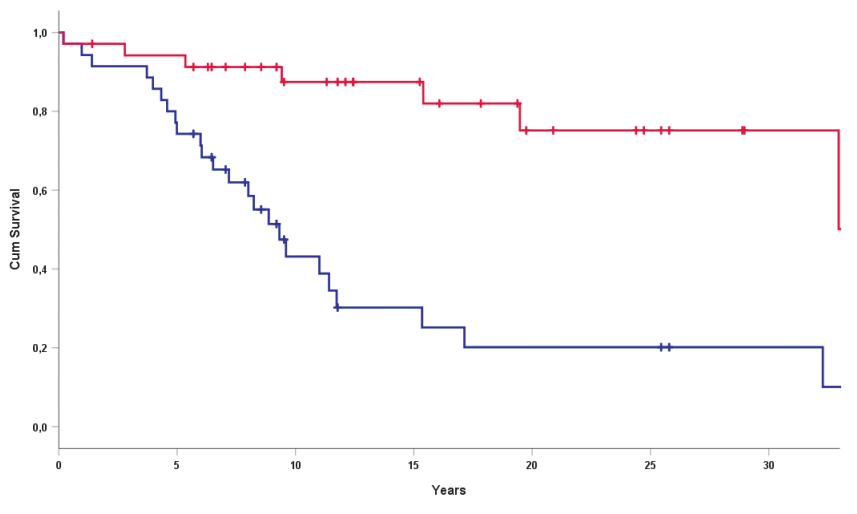

Figure 2. Survival rates in the total FA group ( $n=35)$ : EFS (blue)/0S (red) graphs. 0S E=7 (50.1 $\pm 21.4 \%) ; ~ E F S ~ E=24$ (10.1 $\pm 8.3 \%)$

Overall and event-free survival among the Fanconi anemia patients subjected to HSCT are shown in Fig. 3.

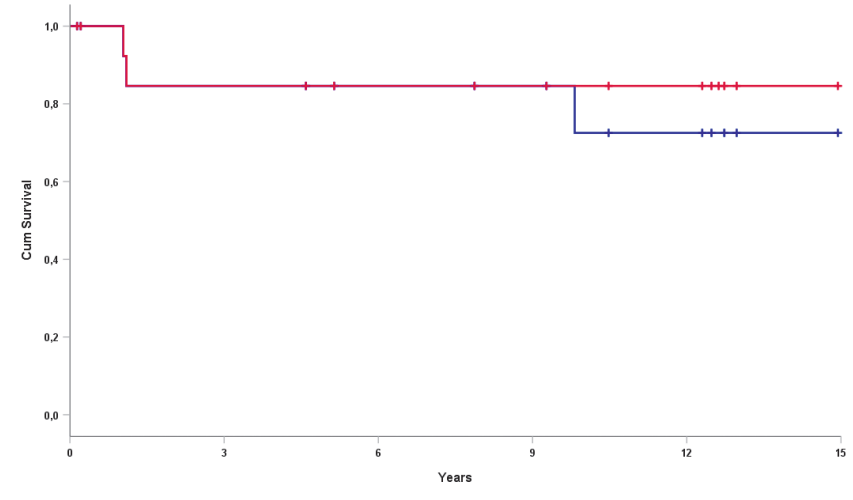

Figure 3. Survival rates in FA patients after HSCT (15

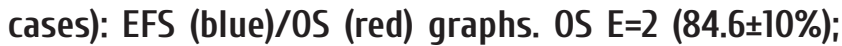
EFS E $=3(72.5 \pm 13.1 \%)$

\section{Long-term monitoring}

A lifelong and careful multidisciplinary follow-up of patients with FA is essential for early detection of bone marrow failure or any malignant disease $[8,9,10]$.

The outpatient care includes long-term follow-up by hematologist/oncologist or bone marrow transplant specialist. 
The following surveillance program should be scheduled for all the FA patients, whether they underwent allogeneic HSCT or not:

Evaluation by oncologists in order to check for signs of head and neck tumors, oral cancer, and gynecologic cancers (including breast carcinoma) once in every 6 months.

Hematological evaluation (every 6 months) due to the risk of bone marrow failure, myelodysplastic syndrome or acute leukemia. One should remember that $1 / 3$ of FA patients may maintain mild/moderate cytopenia, while $2 / 3$ cases will later develop progression.

Examination by specialists in endocrinology. Endocrinopathies, including thyroid dysfunction, growth hormone deficiency, and glucose intolerance, are common in patients with FA, even in ones without history of HSCT.

- Examination by specialists in dermatology, hearing, cardiology, pulmonology (every 12 months).

- Recommendations: no smoking, no alcohol use, correct oral hygiene, limited radiation exposure, limited sun and ultraviolet exposure.

- Human papilloma virus vaccination should be initiated at nine years in order to reduce the risk of gynecologic cancer in females and possibly reduce the risk of oral cancer in all individuals.

\section{Conclusion}

While HSCT is a demanding medical procedure in patients with FA due to disease biology leading to higher transplant-associated risk, it allows achieving very good results when performed in centers with adequate expertise using appropriate conditioning regimens. It reverses bone marrow failure and prevents further development of hematological malignancies. However, the indications have to be considered very carefully. Clinically significant chemotherapy and radiation toxicity due to impaired DNA damage repair mechanisms have historically made allogeneic HSCT for patients with FA extremely challenging. Chronic graft-versushost disease of mouth and/or genitourinary tract has been associated with higher baseline risk of spinocellular carcinoma. HSCT may also increase the risk of other secondary solid tumors and therapy-related MDS or leukemia as it does the non-FA population, but to greater extent. Renal failure is rare in patients with FA despite the fact that about one-quarter of them have structural abnormalities involving kidneys and urinary tract. Renal function may be compromised during and after HSCT by chemotherapy and calcineurin inhibitors toxicity. HSCT can restore long-term hematopoiesis and cure the hematologic complications of FA; however, when compared with age-matched controls, these patients do not achieve complete health or normal life expectancy. The risk of long-term disease- or transplantation-related complications remain and patients with FA are still at risk of conditions caused by congenital anomalies, endocrinopathy, and cancer. Still, HSCT significantly increases a life span if indications were chosen carefully. However, a lifelong multidisciplinary follow-up of all patients with FA is essential for early detection of bone marrow failure or any malignant disease. Preventive measures include minimizing radiation exposure and contact with harmful substances (including smoking). Vaccination against human papillomavirus is recommended to reduce the risk of gynecological cancer in women and oral cancer in all subjects.

\section{Conflict of interest}

None declared.

\section{References}

1. Alter BP, Giri N, Savage SA, Rosenberg PS. Cancer in the National Cancer Institute inherited bone marrow failure syndrome cohort after fifteen years of follow-up. Haematologica. 2018; 103(1): 30-39.

2. Fiesco-Roa MO, Giri N, McReynolds LJ, Best AF, Alter BP. Genotype-phenotype associations in Fanconi anemia: A literature review. Blood Rev. 2019; 37: 100589.

3. Soulier J, Leblanc T, Larghero J, Dastot H, Shimamura A, Guardiola P, et al. Detection of somatic mosaicism and classification of Fanconi anemia patients by analysis of the FA/ BRCA pathway. Blood. 2005; 105(3): 1329-1336.

4. Bogliolo M, Pujol R, Aza-Carmona M, Munoz-Subirana N, Rodriguez-Santiago B, Casado JA, et al. Optimised molecular genetic diagnostics of Fanconi anaemia by whole exome sequencing and functional studies. J Med Genet. 2020; 57(4): 258-268.

5. Dufour C. How I manage patients with Fanconi anaemia. Br J Haematol. 2017;178(1):32-47

6. Paustian L, Chao MM, Hanenberg H, Schindler D, Neitzel H, Kratz CP, et al. Androgen therapy in Fanconi anemia: A retrospective analysis of 30 years in Germany. Pediatr Hematol Oncol. 2016; 33(1): 5-12.

7. Alter BP, Rosenberg PS, Brody LC. Clinical and molecular features associated with biallelic mutations in FANCD1/ BRCA2. J Med Genet. 2007; 44(1): 1-9.

8. Kutler DI, Auerbach AD, Satagopan J, Giampietro PF, Batish SD, Huvos AG, et al. High incidence of head and neck squamous cell carcinoma in patients with Fanconi anemia. Arch Otolaryngol Head Neck Surg. 2003; 129(1): 106-112.

9. Kelaidi C, Makis A, Petrikkos L, Antoniadi K, Selenti N, Tzotzola V, et al. Bone marrow failure in Fanconi anemia: clinical and genetic spectrum in a cohort of 20 pediatric patients. J Pediatr Hematol Oncol. 2019; 41(8): 612-617.

10. Dietz AC, Savage SA, Vlachos A, Mehta PA, Bresters D, Tolar J, et al. Late effects screening guidelines after hematopoietic cell transplantation for inherited bone marrow failure syndromes: consensus statement from the second Pediatric Blood and Marrow Transplant Consortium International Conference on late effects after pediatric HCT. Biol Blood Marrow Transplant. 2017; 23(9):1422-1428. 


\title{
Анемия Фанкони в Чешской республике: роль транс- плантации гемопоэтических стволовых клеток и длительного наблюдения
}

\author{
Петр Седлачек, Петра Кеслова, Петр Смишек, Мартина Сукова, Марцела Маликова, Спирос Тавандзис, \\ Ярослав Чермак, Ян Стари \\ Департамент детской гематологии и онкологии, 2-я медицинская школа Карлова Университета, университетский \\ госпиталь Мотол, Прага, Чешская республика
}

\section{Резюме}

Анемия Фанкони (АФ) - редкий синдром с гетерогенной картиной, сочетающийся с недостаточностью костного мозга и повышенным риском злокачественных новообразований. Хотя АФ часто характеризуется наличием пороков развития, у некоторых пациентов единственным признаком может быть цитопения. В нашей когорте больных диагностика основывалась на повышенной ломкости хромосом с последующим подтверждением генных мутаций.

\section{Методы}

Наша когорта включает 35 пробандов в возрасте от 0 до 24,3 (медиана - 6) лет, у которых была диагностирована АФ в сроки с января 1986 до августа 2020 г. Врожденные аномалии на момент диагноза наблюдались у 5 и цитопения - у 22 пациентов; 8 больных имели семейный анамнез АФ. Генетическое тестирование подтвердило мутации гена FANCA в 24 случаях, FANCG - в 3, FANCD1 - у 4 пациентов и FANCB у двух сиблингов.

\section{Результаты}

По мере наблюдения, у 7 пациентов развились злокачественные новообразования (в том числе - у 4 больных с мутацией FANCD1). У 17 пациентов развилась костномозговая недостаточность, в связи с чем 15 больным была выполнена трансплантация гемопоэтических стволовых клеток (ТГСК) в возрасте от 4,6 до 24,3 лет (медиана - 9,3 года). У всех трансплантированных пациентов было достигнуто стабильное гемопоэтическое приживление. Однако у 2 больных, в связи с неадекватным восстановлением иммунитета, через 12 и 14 мес. после ТГСК развились, соответственно, цитомегаловирусная пневмонияи и инвазивный аспергиллез со смертельными исходами. В одном случае мы диагностировали аденокарциному кишечника через 10 лет и сквамозноклеточную карциному языка через 13 лет после ТГСК. Тринадцать пациентов живы при среднем сроке наблюдения после ТГСК 10,6 (0,3-15,1) лет. При сроках наблюдения с медианой 12,6 (0,2$34,4)$ лет, 28/35 пациентов (80\%) живы, 4 погибли от злокачественных новообразований, двое умерли от осложнений ТГСК, и один больной - в связи с тяжелыми врожденными соматическими пороками.

\section{Выводы}

ТГСК эффективна у пациентов с АФ и костномозговой недостаточностью и предотвращает дальнейшее развитие гематологических осложнений. Необходимо пожизненное и тщательное мультидисциплинарное наблюдение пациентов с АФ для раннего выявления костномозговой недостаточности или злокачественного заболевания.

\section{Ключевые слова}

Анемия Фанкони, соматические аномалии, генные мутации, костномозговая недостаточность, солидные опухоли, трансплантация гемопоэтических стволовых клеток, амбулаторное долгосрочное наблюдение. 